\title{
Representation of Nostalgic Memories for Home in African Diasporic Poetry: Critical Analysis of Selected Poems of Mahtem Shiferraw
}

\author{
Stanley Elias \\ stanleyelias86@yahoo.com \\ Department of English Literature, Universitas Airlangga
}

\begin{abstract}
Nostalgia for home has been a common subject in African diasporic literature. In past four decades the African continent has witnessed an increase of movements of people leaving their home places to new places around the world. These movements whether voluntarily or forcibly have resulted to displaced communities in the world and diasporic community being one of those communities. This paper critically analyses the representation of nostalgic for home in selected poems in of Mahtem Shiferraw and how do such nostalgic memories contribute of in (re)defining the identity of the poet. Central to the analysis it can be argued that nostalgic memories are reflective and restorative of past experiences of home [land] crafted from diasporic sensibilities. As depicted in the selected poems, namely, "Fuchsia", "Synesthesia" and "Talk about Race" the poet represents both the pleasant and unpleasant past life experiences she has gone through while in Africa and later in America. Also nostalgic memories re/defines the inseparable forged identity of the poet from reconstructed past as an African in America. However, according to the discussion, the traditional sense of nostalgia is challenged as the poet yearns for the significant moments of home [land] while remaining in the foreign land.
\end{abstract}

Keywords: diasporic literature, home; nostalgic memories

\section{Introduction}

The epic story of Odysseus in Homer's epic poem "The Odysseus" can provide best understanding of the term "nostalgia". The story tells the Odysseus final days of hardship in the Great Trojan War where he went to fight for his people. According to Andersson (2011) the seven years that Odysseus had spent in Ogyia island projects to psychological phenomenon under discussion. During these seven years in Ogyia Island, the seductive and possessive nymph, Calypso offered Odysseus immortality. According to Homer (1921) in The Odyssey, Trans, as cited in (Sedikides, Wildschut and Baden, 2004) Odysseus rejected the offer because he wanted to reunite with his family in Ithaca (his homeland).
In the story, Odysseus was led by the desire of returning "nostos" (Greek) and this desire of returning home (nostos) resulted to psychological pains called algos. Consequently, the two Greeks roots of nostos and algos led to the coinage of the term "nostalgia" (Hofer,1688) which interpretively means the "psychological pains caused by unrelenting yearning to return to ones' homeland or simply homesickness (Hofer, 1688; Daniels, 1985; Casey, 1987; Sedikides, Wildschut and Baden, 2004:200-201). Since its coinage in the late $17^{\text {th }}$ century, nostalgia has undergone several reviews to respond the academic needs in wide range of fields. For instance, it has been viewed as mental illness and an incurable modern condition in the end of $18^{\text {th }}$ and early 19th century (Davis,1977), as the longing for 
bygone times or a mode of selective past memories (Casey, 1998), as an imaginative enrichment of the emotional aspects inherent to nostalgia during the Romantic Era (Boym, 2001) and as "a form of melancholia caused by prolonged absence from one's home or country" (Simpson, 1989) as cited in (Feldbrügge, 2010:27). In similar trend in the $20^{\text {th }}$ century nostalgia was reviewed and redefined to reflect contemporaries of the academia (Feldbrügge, 2010). Subsequently, nostalgia was used to signal sentimental yearning of any object, event or place in the past (Davis, 1977).

This paper however follows heavily the Svetlana Boym (2001) conception of nostalgia. Boym (2001) in The Future of Nostalgia emphasizes on the significance of space to the concept of nostalgia. Though Boym appreciates the contribution of his predecessors in the area, he stresses that nostalgia is associated with various acts of time and space distanciation from the regulation of nation states to globalization (Boym, 2001; Legg, 2004). Boym identifies that nostalgic memories often gyrate around the lost home and around no place of habitation (Legg, 2004; Boym, 2001). Subsequently, Boym proposes two types of nostalgic memories namely restorative nostalgia and reflective nostalgia. Restorative nostalgia relates to the memories of place. In other words, Legg (2004:100) restorative nostalgia describes memories of geography of belonging and identity forged in a specific landscape of which one is inseparable from it. Reflective nostalgia on the other hand appreciates shattered fragments of memories and temporalizes space (Boym, 2001). For Legg (2004) reflective memories concern with actual and imaginaries places but gives no habitation of one attached to it (them). Individuals with reflective nostalgia will wallow on the sense of homecoming though remain in exilic places they are hosted. This paper in particular, critically analyses the spaces of nostalgic memories in of selected poems of Mahtem Shiferraw's book Fuchsia. It particularly, examines the place of nostalgic memories in connecting the past and present identities of the poet through space and time.
This study is built on what Safran (1991) argues that for whatever reasons of migration, most migrants suffer from the pains of being away from home, memories of homeland and agony of leaving everything familiar at home. Thus, nostalgia becomes the very recurring subject in most $d$ migrant literatures including those of diasporic writers. Frequent dwelling of nostalgia in diasporic literature is often entrenched to retained memories of the diaspora's homeland(s). As of this reason, George (1996) claims provocatively that all fiction of the migrant is homesickness.

Of a particular note, while nostalgia seems to incline to someone going back to a physical home place as it has been traditionally conceived, recent trends on globalized movements, current place of technologies in our lives and other influences have not only added complexity in understanding of nostalgic memories but also have led fluidity of the "home" conception. In the view of the argument, Neelima (2014: 33) responds that

Nostalgic feelings may not just revolve around going back to one's home in a tangible, physical sense of the term". "Nostalgic feeling can be a subtle psychological manifestation of a longing to recapture an emotional or spiritual connection and [sic] can also be a mourning of sorts for sentiments that have been dissipated or misunderstood or even disappointed with one's own failed potential.

Neelima observation appears to echo the fluidity on the conception of home in the contemporary diaspora where home is not necessarily a physical or tangible place. Thus, one may selectively recollect and mourn on memories of the past physical and ideal home. In similar view, as pointed out earlier, Boym (2001) explicates that reflective nostalgic memories may revolve around one longing to recapture imaginary home yet still remaining in exilic place is hosted.

On the other hand, nostalgic memories in diasporic writings are argued to reconnect the past and present of the writers of the diasporic [migrant] literature. According to 
Buikema (2005), (D'Costa, 2006) and Swamy (2013:5) "the sense of nostalgia is often seen among the dislocated and displaced people in most of the diaspora writings" and contributes to identity re/invention as they try to adjust to new environments. Of course, in the process of adjusting to the host place, diasporas come across with convoluted memories of separation from their homeland about people, culture and language. Conforming on the foregoing view, the African continent has witnessed the increase of movements of people to other countries in the world due to cultural, political, economic and social upheavals and so forming larger displaced community in the world in past four decades. Though my study focuses on the contemporary diaspora, I am aware on the contribution of a historical slave trade and colonialism to the creation of early African diaspora around the world. Both of these movements (migrations, mobility and globalization) whether voluntarily or forcibly have resulted to displaced communities around the world including diasporic communities in the mention. In fact, the surrounding circumstances that necessitated the departure of these African diasporic communities from their homelands have influenced the way communities feel about and associate with their homelands. Rijsdijk (2015) in Nostalgia and the ( re ) construction of South African identity in District 9' observes that authors who seek continuity with their past always do so through nostalgia. Thus, this study aims to offer a critical analysis of the nostalgic memories in the selected poems of Mahtem Shiferraw book Fuchsia in diasporic contemporaries.

Mahtem Shiferraw was born in Eritrea, grew up in Ethiopia and now lives in United States of America. She is a poet, story composer, visual artist and an activist. She was nominated for Best of Net in 2013 and her story 'The River' entered the final list at Glimmer Train Press Open Fiction Fuchsia is Shiferraw's debut collection poetry book published by University of Nebraska Press in 2016. The book won the Sillerman First Book Prize for African poets and secured place in African Poetry Book Series. The poems in Fuchsia are crafted metaphorically with use of colours which evoke detailed memories of the migrant's life in different space and time. The poems journey the readers to a convoluted experience of the author while in Africa and as well as migrant in America. In the foreword of the book, Kwame Dawes articulates that it is book of displacements, nomadic life, memories of pleasure, grief, and loss and identity search of the contemporary diasporic communities'. Poems in Fuchsia interrogate the surrounding environments that might have lead the poet's departure to America and the latter effects on her identities and belongingness as a part of displaced community but also to other migrants who pass(ed) the same experience. Kwame Dawes comes again that poems in Fuchsia invite us to spaces of 'home' through time and geography (Shiferraw, 2016:ix). The notion of home is central in the analysis of spaces of nostalgic memories in this study.

In terms of methodology and scope of the study, this paper is largely textual analysis based research. I therefore first use close reading to analyze the representation of nostalgia in selected poems of Shiferraw namely "Fuchsia", Synesthesia" and "Talk about Race" as depicted through the use of words, symbols and metaphors without considering external factors as advocated under new criticism. This is followed by contextual method. I use this method to find the association of selected poems with contexts in which they are produced. It is in this section where the relevance of Shiferraw's biography becomes into considerations. Close reading and contextual methods pave a way to thematic analysis method. Guided by the topic under discussion I explore the thematic representation of spaces of nostalgic memories in selected poems from Fuchsia.

\section{Discussion}

\section{Restorative Nostalgic Memories for Home at Distant Place and Time}

Situating "Fuchsia" in diasporic sensibilities, Shiferraw creatively represents the migrant's experiences in the spectrum of nostalgic memories of place, time and people. On the surface of the poem of "Fuchsia", the poet recalls and yearns for her childhood and family experiences of her homeland in Africa. 
Through the persona Addis Ababa signals place where they (her and the family) dwell and comfortably, secure, and emotionally and culturally providing. These lost memories of childhood and of her family are mobilized around Addis Ababa, one of the physical homeland of the persona. For Legg (2004) such memories restore the lost home(memories) of an individual from which the persona is inseparable from. Reiterating Boym (2001) on restorative nostalgia, Legg (2004) adds that memories about the lost home are reconstructed and mobilized to ascribe geography of belonging in a specified landscape. Accordingly, Addis Ababa forges the inseparable identity with the poet in positioned her exilic locale. In "Fuchsia" the persona takes readers through an emotional and selective pleasant past memories of her 'Ethiopianness' in Addis Ababa as depicted in the following lines. "When I was little, growing up in, Addis Ababa, my father bought the fattest sheep from street vendors for holidays...." (1-3). In the foregoing lines of the poem, "the poet recalls and yearns for her pleasant past of her childhood while in Addis Ababa that she cannot have an access with at the moment. The persona longs for varieties of meals from the butchered sheep as of the poet's traditions like berbere and other spiced cuisines evokes sentimental mourning yet reconstructed past home of the poet.

\section{Nostalgic memories for home communal living and traditions}

Furthermore, as pointed out earlier in the epic story Odysseus in Homer's epic poem, sentimental yearning for home is surrounded to by number of factors similar to what Webster (2010) conceives about home[land] that at home there is significant assurance security, comfortability and emotional attachments and sense of belongingness. In the poem of "Fuchsia" though the poet metaphorically ends the poem with horrific memories of home, she still longs for the separation of her distanced home communal living and traditions. According to Rubenstein (2001) in Home Matters: Longing and Belonging, Nostalgia and Mourning in Women's Fiction acknowledges that 'culturally displaced or exiled people may mourn their separation from home/land, community, language, and/or cultural practices. Rubenstein (2001:5)stresses that the displaced communities culturally mourn their separation from home as she boldly use the term;

'cultural mourning' to signify an individual's response to the loss of something with collective or communal associations: a way of life, a cultural homeland, a place or geographical location with significance for a larger cultural group, or the related history of an entire ethnic or cultural group from which she or he feels severed or exiled, whether voluntarily or involuntarily.

In the light of Rubenstein argument through the persona, the poet in the poem of "Fuchsia" orchestrates the lost past memories of communal living of the entire community in Addis Ababa. Of a particular note, communal living which characterizes daily living of many African societies culturally is reflected as they could share the other part of the sheep (head) to the neighbors for them to make soup as represented in the following verses.

insides, and knife slashing between slabs of organs,

all to be eaten differently-bones of the rib cage

deep fried, bleeding texture of kidneys minced into

bite-sized shapes and soaked in onion and pepper oil,

small blades of the stomach dutifully cut into long

strips, and mashed with spiced butter and berbere. Even

the skin, bloodying fur, will be sold to passing vendors, its

head given away to neighbors who will use it for soup. (1-3)

The momentous past memories of communal life and the associated traditions in Addis Ababa trigger emotional attachment of homeland that she is inseparable from while living in America as immigrant. Unlike in the host land (America) where the poet lives at present, communal living is a typical African way of living of many African societies from which she mourns and attached with. 


\section{There is no habitation anymore: Nostalgic memories of the shattered homeland}

On the other hand, the poet represents the nostalgic memories of disturbed homeland that renders no place of habitation. According to Boym (2001) such memories are reflective nostalgic and emanate as one tries to reconfigure the shattered memories of homeland that offer [ed] no place of habitation. As of the poem of "Fuchsia" a sensual imagery of violence in the end of the poem and memories of death metaphorically represents a convoluted yet alludes important experience of the poet while in Addis Ababa. For instance the lines, "If you ask how to say "burgundy" in Tigrinya, you will be/ told, it's the color of sheep-blood, without the musty smell/ of death attached to it. It's also the color of my hair, dipped" (1-3) are allusive of memories and symbolic representation of state of violence in Addis Ababa, Ethiopia. It is historically true the poet's homeland has episodically experienced intra and interstate wars especially since 1974. According to Catlin(1993) poet's home is known worldwide as the "arc of crisis" from which death, injuries and displacements characterize the area since 1974.

Conforming to Boym (2011) and Havlena (1992) who argue that nostalgia may be stimulated by memories of hard times or times of turmoil, shattered and fragmented memories in spatial and temporal settings, the poet situates the poem of "Synesthesia" in poetic trope of violent, painful and fearful memories of homeland. Through the persona's voices, the metaphorical use of colours journey the readers through convoluted memories of violence, troubles, wounds, restlessness, sadness and the entire post -violence scenery of poet's home. The following verses provide an exemplification of the violent and painful memories of the poet.

White sometimes comes back at odd hours. White are stranger's eyes drenched in sadness. White is the uniform of doctors, the smell of alcohol and something mad. White is absence. Purple comes back as shoes, American shoes. Sky and blood under a quiet shadow. The shadow of a young tree planted in memory of a murdered teacher in high school. And the milky paste of over-ripe figs spurting prematurely, spiking insides. Purple is warmth in mid-July, when rain hails on corrugated tin roofs and the leaning green arms of lonely corn plants.

Yellow is crying; it's a bell, a cathedral in Asmara? A school? Or the shriek of a mass funeral. Yellow is dead. But listen to black. Listen to black notes, black heart, listen. Black is art. Not of the artist, the art of being. The painful art of memory. Here's to remembering (30-31)

In the foregoing fragment of the poem of "Synesthesia", the poet alludes the time of crisis, of course the time of violence and instability of her African homes. As pointed out earlier that the poet has Eritrean-Ethiopian origins, the two nations went through twoyear long war from May 1998 to June 2000 causing deaths and more than 100,000 causalities. According to Tronvoll (2017) the dispute over the border has continued to be the main source of instability in the region of Horn of Africa until today. Through the persona's voice the poet presents to readers the painful memories of people, place and time. The poet emotionally recalls the time when causalities of violence are being attended by doctors in white uniform, death of people in Asmara, Eritrea (as people are being murdered in the place and absenteeism of people in the post-violence landscape). Consequently, the poet's neighbor's houses in Abbay are empty with no one living in. As it is depicted in the fifth stanza of the poem of "Synesthesia", there is a grief on people's face in the place as it is depicted in the first verse of the poem "Blue are the waters embedded in my grandmother's eyes. Blue is" (30-31). Through persona's voice the poet orientates readers through chaotic incidents of her African home from different space and time. 


\section{The Past and Present Experiences being connected through Nostalgic Memories}

Accordingly, Addis Ababa and Eritrea are significant places that offer forged inseparable identity of the poet on her past and present experiences the while living in another place. The nostalgic memories of the poet's homeland in Africa not only describes the identity of the poet but also maintain and represents experiences of the migrant (poet) in the continuum of Africa and America. This confirms Davis (1979) hypothesis that nostalgic memories allow people to retain and adjust their identities when they enter new life experiences. Therefore nostalgic memories in other words function to protect personal identity against threats of discontinuity as a result of being away from home(Bassett). Alternatively Andersson (2011:29)puts that " people who face existential disruptions, like moving to a new location, changes in an intrapersonal relationship, occupational crises (e.g. layoffs), loss of family members etc., will be more nostalgic about the past than those who maintain greater continuity in their lives". In the poems of "Fuchsia" and "Synesthesia" the poet chooses Addis Ababa/Asmara to associate memories of her past that define her "otherness" as an Ethiopian/ Eritrean and Afro American while in America. Of course, it is from her past that leads her "otherness" in the new locale she now resides. Following the assertion the poet confirms her "otherness" in the poem, "Talks about Race" (20). The lines "I am "other"; it is such/an indistinguishable form, beyond the construct of the proper self" (20) defines her identity from reconstructed past as an African in America. For Lowenthal (1989) "We are at home in [the past] because it is our home - the past is where we come from".

Of a particular note, Shiferraw's poems of "Fuchsia" and "Synesthesia" also capture and communicate traumatic experience of leaving home through the use of memories colored by nostalgia of time, place and people. Consequently, the experience that the poet goes through follows (Andersson) who argues that nostalgic feelings lead to complex and emotional memories that rises a certain mood as the poet struggles to immerse herself in the foreign land of multicultural settings.

\section{Conclusion}

On the contrary of what Hofer (1688) Daniels Eugene B (1985) and Sedikides, Wildschut and Baden (2004) who argue that nostalgic feelings revolve around one going back to tangible home place, central to this analysis, it can be argued that nostalgic memories may evolve without one yearning to go back to a home place as in "Fuchsia" and "Synesthesia". The unusual experience that the poet brings in the ending of "Fuchsia" alludes the memories of violence that would have influenced her yearning of inhabitable home. Also it can be argued that nostalgic memories in "Fuchsia" ar selective past of the lost home that among other things offered emotional security, belongingness and comfortability to the poet once attached with while in Addis Ababa. But for Davis (1997) in Yearning for Yesterday: A Sociology of Nostalgia memories of this kind that may not require one to go back to a physical home place offer the migrant or the dislocated with the identity and protect one from disjointedness with her past during moments of adjustments in the exilic environments. Thus, it is undisputable fact that displaced individuals deploy nostalgia to connect life experiences of different spaces and time. It can be argued that nostalgia resonates in almost every work of the migrant literature because migrants try to connect dots of their life experiences of different space and time as they inscribe their adjustment to new life experience

It can therefore generally be argued that nostalgic memories are reflective and restorative of past experiences of disrupted individual in diasporic sensibilities. As it is depicted in the selected poems, namely, "Fuchsia", "Synesthesia" and "Talk about Race" the poet represents both the pleasant and unpleasant past life experiences she has gone through while in Africa and later in America. However, as of this discussion, the traditional sense of nostalgia is challenged as the poet yearns about the significant moments of home[land] while remaining in the foreign land. 


\section{References}

Andersson, Jimmy. Defining Nostalgia and Its Functions: A Review. N.p., 2011.

Bassett, Jonathan F. "An Experimental Test of the Discontinuity Hypothesis: Examining the Effects of Mortality Salience on Nostalgia." Journal of Articles in Support of the Null Hypothesis 4.1 (2006): 1-8.

Boym, Svetlana. The Future of Nostalgia. New York: Basic Books, 2001.

Buikema, Rosemarie. “A Poetics of Home: On Narrative Voice and the Deconstruction of Home in Migrant Literature." Migrant Cartographies: New Cultural and Literary Spaces in Post-Colonial Europe 1986 (2005): 177-187.

Casey, Edward. "The World of Nostalgia." Man and World 20 (1998): 361-384.

Catlin, Lieutenant Colonel John D. Ethiopia: A Case Study for National and Military Strategy in the New World Order. Pennsylvania: N.p., 1993.

D'Costa, Alzena. "Anglo-Indian Nostalgia : Longing for India as Homeland." February (2006): 24-25.

Daniels Eugene B. "Nostalgia and Hidden Meaning." American Image 42 (1985): 371-383.

Davis, Fred. "Nostalgia, Identity and the Current Nostalgia Wave." Journal of Popular Culture 11.2 (1977): 414-424.

---. Yearning for Yesterday: A Sociology of Nostalgia. New York: NY: Free Press, 1979.

Feldbrügge, Eingereicht von Astrid. "Nostalgia , Home and Be-Longing in Contemporary Postapartheid Fiction by
Zakes Mda and Ivan Vladislavi ć Dissertationsschrift Eingereicht von Astrid Feldbrügg." (2010): n. pag.

George, Rosemary Marangoly. The Politics of Home. Postcolonial Relocations and Twentieth-Century Fiction. Berkely: University of California Press, 1996.

Havlena, Susan L. Holak and William J. "Nostalgia: An Exploratory Study of Themes and Emotions in the Nostalgic Experience"." In NA - Advances in Consumer Research Volume 19, Eds. John F. Sherry, Jr. and Brian Sternthal, Provo, UT : Association for Consumer Research. N.p., 1992. 380-387.

Hofer, Johannes. "Medical Dissertation on Nostalgia." Bulletin of The Institute of the History of Medicine 2 (1688): 376391.

Legg, Stephen. "Memory and Nostalgia." Cultural Geographies 11.1 (2004): 99107. Web.

Lowenthal David. "Nostalgia Tells It like Itwasn't." In The Imagined Past, . N.p., 1989.

Neelima, C. "The Place of Nostalgia in Diaspora Writing: Home and Belonging in The Fiction Of Bharati Mukherjee." International Journal of English and Literature (IJEL) 4.6 (2014): 33-40.

Rijsdijk, Ian-Malcolm. "Nostalgia and the ( $\mathrm{Re})$ Construction of South African Identity in District 9." May (2015): n. pag. Web.

Rubenstein, Roberta. Longing and Belonging Nostalgia and Mourning in Women's Fiction. New York: Palgrave, 2001. Safran William. "Diasporas_in_Modern Societies_Myths_of_H (1).Pdf."1991: n. pag. Print. 
Sedikides, Constantine, Tim Wildschut, and Denise Baden. Nostalgia: Conceptual Issues and Existential Functions. N.p., 2004. Web.

Shiferraw, Mahtem. Fuchsia. Lincoln: University of Nebraska, 2016.

Simpson, J.A and E.S.C. Weiner. Oxford English Dictionary. Volume X. N.p., 1989.

Swamy, Mrs. G. Serwani Venkata. "Immigrant Identity, Nostalgia for Home and Home Land: A Perception in Chitra Banerjee Divakaruni'S the Vine of Desire." I Issue III August I Issue III (2013): n. pag.

Tronvoll, Goitom Gebreluel \& Kjetil.

"Ethiopia and Eritrea: Brothers at War No More." www.aljazeera.com. N.p., 2013. Web. 3 Nov. 2017.

Webster, Magda B. Home as the Intersection of Place and Cultural Identity: The Idea of Home in Diaspora and Art as a Response to an Immigrant's Nostalgia. N.p., 2010.

Appendices (Selected Poems from Mahtem Shiferraw's book Fuchsia)

\section{“Talks about Race"}

I have dark skin, dark face, and darkened eyes -

the white resides only outside the pupil.

I don't know how to think of this -

I wasn't taught to notice one's colors;

under the sun, everyone's skin bounces streaks of light.

Which do I claim? It is difficult to explain the difference between African \& African American the details escape me, thin paper folding the involucre of a burning fire.

I am "other"; it is such an indistinguishable form, beyond the construct of the proper self.

Sometimes I am asked

if I am Indian, Middle Eastern, or Biracial;

I don't know what to say to these people who notice the shape of the eye before its depth the sound of the tongue before its wisdom the openness of a palm before its reach.

And what to those who call me, "African"? Don't they know I can count the years spent back home wishing I knew I was "African"? 
And how to cradle, and contain the disappointment that is rekindled whenever someone does NOT know my Ethiopia, my Eritrea.

I don't know how to fit, adjust myself within new boundaries nomads like me, have no place as home, no way of belonging.

\section{"Synesthesia"}

White is a color,

black is art. Nod to those before you.

Brown is a sense of being, and dark hovers

only beneath the shadows of necks -

those who fear it most. Here is to fear.

Red are the tip of shoes of the woman

who waited in the bathroom patiently when I was

only three - to steal my mother's ruby earrings. White

is the unsafe silence of bathroom walls, and their morbidly cubic nature. White is water running under my feet, the innocent screams of school children at lunch hour.

Brown is the anomalous texture of curtains from my childhood. Brown is also the parched wood of a small coffee-grinder my mother used. Brown as in the intimate angles of sharply cut ambasha my grandmother made, flour and water, lemon skin and cinnamon shreds, the dark heads of raisins, while on a cargo plane back to Ethiopia, the tired eyes of war-victims and their slow recovery. Brown is also the color of my skin, but I didn't know it then.

Blue are the waters embedded in my grandmother's eyes. Blue is the whisper of the Nile, Abbay. Blue is the color of the brave. Blue are the walls of empty neighbors houses and the insides of their living room. Blue is skimmed milk tearing the sky.

White sometimes comes back at odd hours. White are stranger's eyes drenched in sadness. White is the uniform of doctors, the smell of alcohol and something mad. White is absence. Purple comes back

as shoes, American shoes. Sky and blood under a quiet shadow. The shadow of a young tree planted in memory of a murdered teacher in high school. And the milky paste of over-ripe figs spurting prematurely, spiking insides. Purple is warmth in mid-July, when rain hails on corrugated tin roofs and the leaning green arms of lonely corn plants.

Yellow is crying; it's a bell, a cathedral in Asmara? A school? Or the shriek of a mass funeral. Yellow is dead. But listen to black. Listen to 
black notes, black heart, listen. Black is art. Not of the artist, the art of being. The painful art of memory. Here's to remembering.

\section{"Fuchsia"}

It's a deep purple thought;

once it unraveled prematurely

and its tail broken, leaving a faint trail

of rummaging words.

When I was little, growing up in

Addis Ababa, my father bought

the fattest sheep from street vendors

for the holidays. He would

pull its curled horns, part the wet

rubber lips to check the sharpness

of its teeth, grabbed its tail, separated

the hairs in the thick bed of fur. Later, he will

bring it home, unsuspecting creature, tie

it to a pole in the garden, feed it the greenest

grass until its sides are swollen and heavy. It will be

slaughtered in the living room, kitchen knife

cutting in a precise angle through its neck, the

blood splattered on the blades of grass gently laid

by my mother on the cement floor, one last

comfort before its end. Come afternoon, it will

hang upside down, viscous wet smell emanating from its

insides, and knife slashing between slabs of organs, all to be eaten differently-bones of the rib cage deep fried, bleeding texture of kidneys minced into bite-sized shapes and soaked in onion and pepper oil, small blades of the stomach dutifully cut into long strips, and mashed with spiced butter and berbere. Even the skin, bloodying fur, will be sold to passing vendors, its head given away to neighbors who will use it for soup.

In September, the street shoulders of Addis Ababa flood with yellow daisies, creating patches of sunlight in rainy days. But every so often, a mulberry daisy is spotted, its head barbarous in a field of gold, dirty purple in its becoming.

The first time I saw a plum, it was lying in a pool of swollen mangoes and papayas at a local grocery store, and I held it in my hand, wanting to pierce the luminous nakedness of the skin with my nails and teeth.

If you ask how to say "burgundy" in Tigrinya, you will be told, it's the color of sheep-blood, without the musty smell of death attached to it. It's also the color of my hair, dipped in fire. And the greasy texture of clotted arteries, and the folding 
skin of pineapple lilies, and the sagging insides of decaying roses, and the butterfly leaves of blooming perennials, and spongy strawberries drowning in wine.

Right before dusk, when the skies are incised with a depression of shades, oranges escaping from one end into the mouth of the horizon, freckled clouds unclog suddenly, giving shape to the pelvis of the sky, its sheep-blood visible only for a second, then bursting into flames of golden shadows. In days like these, when the sun's tears are fat and swollen, descending obliquely into the city, we say somewhere a hyena is giving birth, and perhaps it is.

And then, you ask, what is fuchsia-and there's a faint smile, a sudden remembrance, an afterthought in hiding, forgotten smells of wild flowers and days spent in hiding, in disarray. And mulberry daisies carried by phosphorescent winds into the warm skin of sleeping bodies; moments spent between here and there, pockets of emptinesswithout sound, without reckoning. 